\title{
A Theoretical and Experimental Research on the Influence of FDM Parameters on Tensile Strength and Hardness of Parts Made of Polylactic Acid
}

\author{
Dragoș Gabriel Zisopol \\ Mechanical Engineering Department \\ Petroleum - Gas University \\ Ploiesti, Romania \\ zisopol@zisopol.ro \\ Alexandra-Ileana Portoaca \\ Mechanical Engineering Department \\ Petroleum - Gas University \\ Ploiesti, Romania \\ alexandra.portoaca@upg-ploiesti.ro
}

\author{
Ion Nae \\ Mechanical Engineering Department \\ Petroleum - Gas University \\ Ploiesti, Romania \\ inae@upg-ploiesti.ro \\ Ibrahim Ramadan \\ Mechanical Engineering Department \\ Petroleum - Gas University \\ Ploiesti, Romania \\ ing_ramadan@yahoo.com
}

\begin{abstract}
Fused Deposition Modeling (FDM) is a rapid prototyping method, widely used in the manufacture of plastic parts with complex geometric shapes. The quality of the parts manufactured by this process depends on the plastic material used and the FDM parameters. In this context, this paper will present the results of a theoretical and experimental research on how FDM parameters influence the tensile strength and hardness of samples made of PLA (Polylactic Acid).
\end{abstract}

\section{Keywords-3D printing; experimental tests}

\section{INTRODUCTION}

With the increasing complexity of industrial products and the requirements related to environmental protection and resource conservation, new manufacturing technologies are needed. FDM is the most significant technique in Additive Manufacturing (AM) that refers to the process in which successive layers of material are stored in a computercontrolled environment to create a three-dimensional (3D) object [1]. Since 2009 the demand for FDM has grown steadily and many experts believe that this technology has the potential to revolutionize production in many sectors [2]. The main advantages of FDM are [2]: the manufacturing process is simple, allowing the making of parts with complex geometries and cavities, the dimensional accuracy is good, and it is a more cost-effective method compared to other 3D printing techniques. Additive technologies represent a field that is suitable for the needs of today's society through specific interdisciplinary and application possibilities in various areas such as: medicine, engineering, aeronautics, automotive, architecture, etc. However, there are still some limitations and disadvantages, especially in terms of the lower mechanical properties of FDM parts compared to products by conventional methods, such as injection and compression techniques $[2,3]$.
Since mechanical characteristics are extremely important for functional parts, it is necessary to investigate the influence of process parameters on the mechanical performance and geometrical qualification $[3,4]$. Further research is also needed to determine the printing parameters, such as: deposition orientation, layer thickness, and deposition speed, mainly because the relevant information in the literature is diverse in terms of the values obtained by the mechanical characteristics of parts made with 3D printers. This applies to PLA material, which unlike ABS has not been extensively analyzed [5-10]. The novelty of this paper consists in the comparison of different printing parameters (layer thickness and infill percentage), which can be used in order to optimize the mechanical characteristics obtained for different applications.

\section{A COMPARISON OF THE MATERIALS USED FOR 3D PRINTING IN FDM TECHNOLOGY}

FDM has the advantage of using a wide range of materials. Table I shows a comparison between the physical and mechanical characteristics of various such materials used. The data were collected from the manufacturers' data sheets specifications. These values are indicative and depend heavily on the printing conditions. The mechanical properties considered refer to the orientation of the horizontal test specimen (XY orientation). Under these conditions, this paper analyzes the influence of technological conditions of deposition on the mechanical characteristics of the deposited material. Economic, environmental, and safety challenges have caused scientists and economic agents to partially replace petrochemical with biodegradable polymers [11] such as the PLA. 
TABLE I. PHYSICAL-MECHANICAL CHARACTERISTICS OF THE MOST USED FILAMENTS IN FDM TECHNOLOGY [8-10]

\begin{tabular}{|c|c|c|c|c|c|c|c|}
\hline \multirow[t]{2}{*}{ Material } & \multicolumn{7}{|c|}{ Physical-mechanical characteristics } \\
\hline & $\begin{array}{c}\text { Extrusion } \\
\text { temperature } \\
\left({ }^{\circ} \mathrm{C}\right)\end{array}$ & $\begin{array}{c}\text { Bed } \\
\text { temperature } \\
\left({ }^{\circ} \mathrm{C}\right)\end{array}$ & $\begin{array}{l}\text { Density } \\
\left(\mathrm{g} / \mathrm{cm}^{3}\right)\end{array}$ & $\begin{array}{c}\text { Tensile } \\
\text { strength } \\
\text { (MPa) }\end{array}$ & $\begin{array}{c}\text { Specific } \\
\text { Deformation } \\
(\%)\end{array}$ & $\begin{array}{c}\text { Charpy impact } \\
\text { strength } \\
\left(\mathbf{k j} / \mathbf{m}^{2}\right)\end{array}$ & Details \\
\hline PLA & $210 \pm 10$ & $25-60$ & $1.31 \pm 0.02$ & $15.5-72$ & $34.5 \pm 8.1$ & $5.7 \pm 0.4$ & Colored filament \\
\hline $\mathbf{P P}$ & $240 \pm 10$ & 80 & 0.89 & 14 & $>200$ & 10 & Translucent \\
\hline BVOH & $210 \pm 10$ & 60 & 1.14 & 45 & 9 & 21 & Soluble in water \\
\hline PETG & 240 & 80 & 1.25 & $31.9 \pm 1.1$ & $6.8 \pm 0.9$ & $5.1 \pm 0.3$ & Flexible \\
\hline $316 \mathrm{~L}$ & $240 \pm 10$ & $105 \pm 15$ & $5.6 \pm 0.2$ & 561 & 53 & 1110 & Stainless steel \\
\hline ULTEM & $350 \pm 10$ & $150 \pm 10$ & 1.27 & 81 & 3.3 & 6 & Thermoplastic \\
\hline ABS & $210 \pm 10$ & 80 & 1.10 & 33.9 & 4.8 & 10.5 & Very rough \\
\hline
\end{tabular}

\section{EXPERIMENTAL METHODOLOGY}

\section{A. Setting Up Parameters}

The mechanical properties of 3D printed parts are important indicators for evaluating print quality. The experimental research program includes tests performed to determine how the technological parameters of the printing influence the mechanical characteristics of the deposited material. In these conditions, the working parameters of the printer used must be taken into account. The initial data targeted in the experimental determinations were grouped into two categories (Table II). The first category refers to process parameters considered as constant quantities: deposition direction, printing speed, filling pattern, and deposition temperature. The second category is the process parameters considered as variable parameters: layer thickness $(\mathrm{g})$, infill percentage $\left(\mathrm{g}_{\mathrm{u}}\right)$, flow rate $\left(\mathrm{F}_{\mathrm{r}}\right)$. Test specimens were made and were grouped on sets of samples, each set of samples consisting of 5 specimens, belonging to a group of process parameters, highlighted in Table III.

TABLE II. CONSTANT AND VARIABLE PRINTING PARAMETERS

\begin{tabular}{|c|c|}
\hline \multicolumn{2}{|c|}{ Parameters } \\
\hline $\begin{array}{c}\text { Process parameters used } \\
\text { (constant quantities) }\end{array}$ & $\begin{array}{c}\text { Variable parameters of } \\
\text { the technological process }\end{array}$ \\
\hline Build orientation $\mathrm{X}-\mathrm{Y}$ & Layer thickness $(\mathrm{g})$ \\
\hline Print speed $(\mathrm{Ps})-80 \mathrm{~mm} / \mathrm{s}$ & Infill procentage $\left(\mathrm{g}_{\mathrm{u}}\right)$ \\
\hline Deposition temperature $(\mathrm{Dt})-200^{\circ} \mathrm{C}$ & Flow rate $\left(\mathrm{F}_{\mathrm{r}}\right)$ \\
\hline Infill model - lines, $45^{\circ}$ orientated & \\
\hline
\end{tabular}

TABLE III. PROGRAM OF EXPERIMENTAL DETERMINATIONS

\begin{tabular}{|c|c|c|c|}
\hline \multirow{2}{*}{$\begin{array}{c}\text { Layer thickness }(\mathbf{m m}) \text { and } \\
\text { infill percentage }\end{array}$} & \multicolumn{3}{|c|}{ Printing parameters } \\
\cline { 2 - 4 } & $\begin{array}{c}\text { Flow rate } \\
\left(\mathbf{m m}^{\mathbf{3}} / \mathbf{s}\right)\end{array}$ & $\begin{array}{c}\text { Temperature } \\
\left({ }^{\circ} \mathbf{C}\right)\end{array}$ & $\begin{array}{c}\text { Print speed } \\
(\mathbf{m m} / \mathbf{s})\end{array}$ \\
\hline $0.2(100 \%)$ & 6.4 & 200 & 80 \\
\hline $0.2(75 \%)$ & 6.4 & 200 & 80 \\
\hline $0.2(50 \%)$ & 6.4 & 200 & 80 \\
\hline $0.2(25 \%)$ & 6.4 & 200 & 80 \\
\hline $0.15(100 \%)$ & 4.8 & 200 & 80 \\
\hline $0.15(75 \%)$ & 4.8 & 200 & 80 \\
\hline $0.15(50 \%)$ & 4.8 & 200 & 80 \\
\hline $0.15(25 \%)$ & 4.8 & 200 & 80 \\
\hline $0.1(100 \%)$ & 3.2 & 200 & 80 \\
\hline $0.1(75 \%)$ & 3.2 & 200 & 80 \\
\hline $0.1(50 \%)$ & 3.2 & 200 & 80 \\
\hline $0.1(25 \%)$ & 3.2 & 200 & 80 \\
\hline
\end{tabular}

\section{B. Experimental Set-Up}

The adopted material for making the test specimens was PLA. The recommended melting temperature for this material is between $200-220^{\circ} \mathrm{C}$, while the temperature of the heated plate has been set to $60^{\circ} \mathrm{C}$. The filament used to obtain the test specimens was Creality PLA, with a diameter of $1.75 \mathrm{~mm}$ [12]. The specimens were made on the Creality CR-X printer, equipped with 2 extruders, with an extrusion nozzle diameter of $0.4 \mathrm{~mm}$. Work methodology was applied as in Figure 1. The shape and main dimensions of the specimen are shown in Figure 2. The specimens used in this study to assess dimensional accuracy (Figure 3), repeatability and mechanical properties are modeled on American Society for Testing and Materials ASTM D638, Type IV standards for tensile testing of plastic [13].

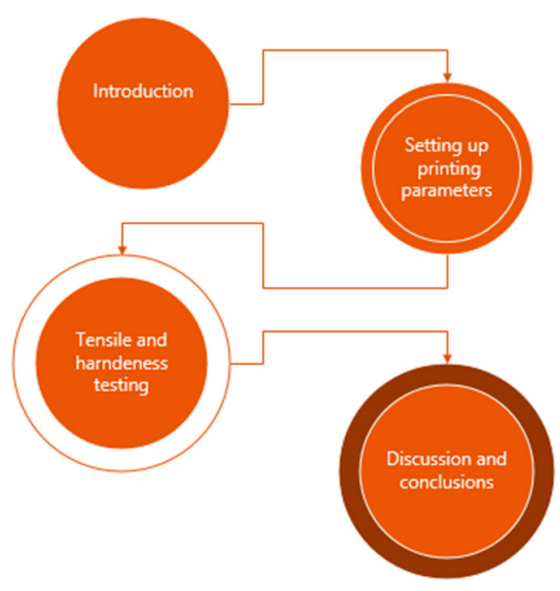

Fig. 1. Work methodology.



Fig. 2. Tensile test specimen's dimesional details [13].

The specimen model was designed using Autodesk Inventor software [14], transformed into STL format, and the G-code was made using the 3D printer software Creality Slicer [15]. In this software the change of parameters was possible. 


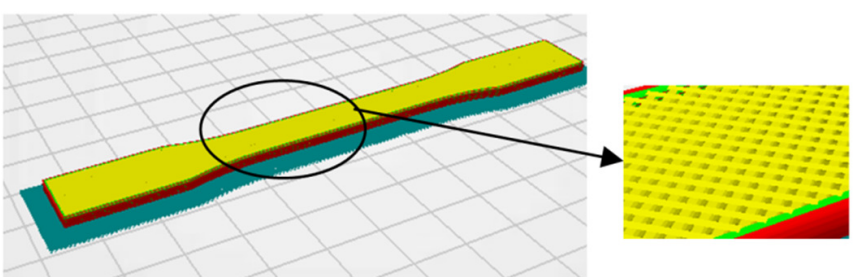

Fig. 3. Representation of the test piece from the Creality Slicer software and the infill method (linear).

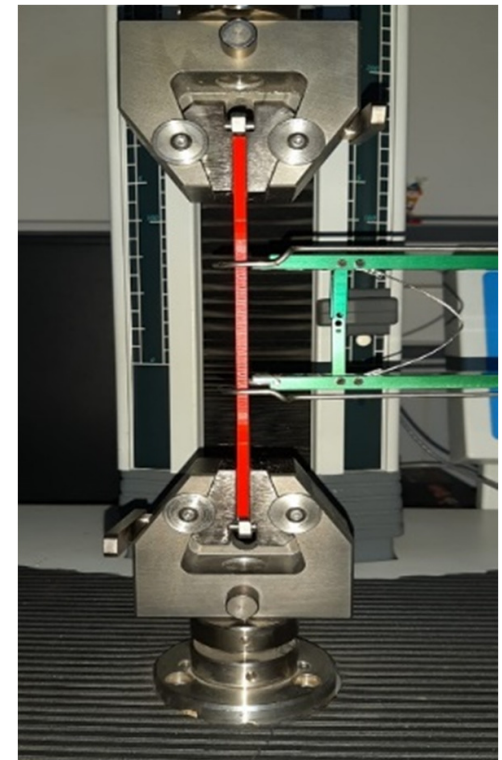

Fig. 4. Electro-mechanical testing machine with a $2.5 \mathrm{kN}$ load cell and a high performance extensometer.

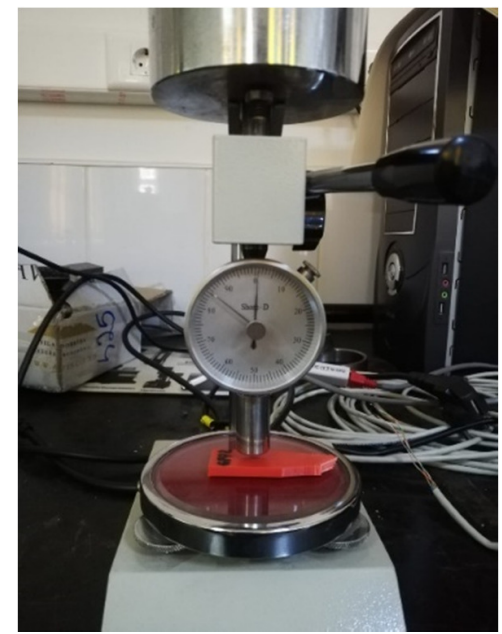

Fig. 5. Shore D type durometer.

Each set of samples consisted of 5 specimens, each belonging to a group of process parameters, highlighted in Table III. A total of 60 specimens were manufactured by 3D printing. The specimens were subjected to mechanical tests to determine the strength characteristics of the material: ultimate tensile strength $\left(\mathrm{R}_{\mathrm{m}}\right)$, elongation at break $(\varepsilon)$, tensile Young's modulus $\left(\mathrm{E}_{\mathrm{l}}\right)$, and hardness (HS). Tensile tests were performed on an electro-mechanical machine with a force cell of $2.5 \mathrm{kN}$, at a speed of $5 \mathrm{~mm} / \mathrm{min}$ (Figure 4). Elongation at break was measured using an axial extensometer (Figure 4). Hardness was measured at the points specified in Figure 3. The values of hardness were determined on 15 specimens, with infill percentage of $50 \%, 75 \%$, and $100 \%$, in 6 points per specimen (Figure 4), with a Shore D durometer (Figure 5).

\section{RESULTS AND DISCUSSION}

The experimental tests were designed to investigate the behavior of plastic parts (PLA), under the action of traction forces, made by 3D printing, taking into account the manufacturing conditions as input factors of the testing process.

\section{A. Tensile Properties Obtained from the Experimental Tests}

The initial information for the tensile tests consisted of the shape and dimensions of the test specimen (Figure 2), the type of plastic used (PLA), 3D printing equipment (electromechanical machine Lloyd LRX Force Tester - Figure 4), as well as the process parameters considered as constant quantities: deposition direction $(\mathrm{X}-\mathrm{Y})$, printing speed $(80 \mathrm{~mm} / \mathrm{s})$, filling pattern (lines), and deposition temperature $\left(200^{\circ} \mathrm{C}\right)$. The process parameters considered as variables were: the thickness of the deposited layer $(\mathrm{g}=0.1 ; 0.15 ; 0.20 \mathrm{~mm})$ and the infill percentage $\left(g_{u}=25 \% ; 50 \% ; 75 \% ; 100 \%\right)$. The experimentally determined quantities were: ultimate tensile strength $\left(\mathrm{R}_{\mathrm{m}}\right)$, elongation at break $(\varepsilon)$, tensile Young's modulus $\left(\mathrm{E}_{\mathrm{l}}\right)$, and hardness (HS). The test methodology was performed in the conditions in which the variation parameters were the thickness of the deposited material layer $\mathrm{g}$ and the infill percentage $g_{u}$. Graphs were drawn that express the dependence of the mechanical characteristics $(\mathrm{CM})$ of the tested specimens according to the infill procentage $\mathrm{CM}=\mathrm{f}\left(\mathrm{g}_{\mathrm{u}}\right)$ for different thicknesses of the deposited layer. Under these conditions, the following dependencies were drawn:

- Figure 6 shows the dependence $\mathrm{R}_{\mathrm{m}}=\mathrm{f}\left(\mathrm{g}_{\mathrm{u}}\right)$ for $\mathrm{g}=0.1 \mathrm{~mm}$ and $\mathrm{g}_{\mathrm{u}}=25 \% ; 50 \% ; 75 \% ; 100 \%$.

- Figure 7 shows the dependence $\varepsilon=\mathrm{f}\left(\mathrm{g}_{\mathrm{u}}\right)$ for $\mathrm{g}=0.1 \mathrm{~mm}$ and $\mathrm{g}_{\mathrm{u}}=25 \% ; 50 \% ; 75 \% ; 100 \%$.

- Figure 8 shows the dependence $\mathrm{E}_{\mathrm{l}}=\mathrm{f}\left(\mathrm{g}_{\mathrm{u}}\right)$ for $\mathrm{g}=0.1 \mathrm{~mm}$ and $\mathrm{g}_{\mathrm{u}}=25 \% ; 50 \% ; 75 \% ; 100 \%$.

- $\quad$ Figure 9 shows the dependence $\mathrm{R}_{\mathrm{m}}=\mathrm{f}\left(\mathrm{g}_{\mathrm{u}}\right)$ for $\mathrm{g}=0.15 \mathrm{~mm}$ and $\mathrm{g}_{\mathrm{u}}=25 \% ; 50 \% ; 75 \% ; 100 \%$.

- Figure 10 shows the dependence $\varepsilon=\mathrm{f}\left(\mathrm{g}_{\mathrm{u}}\right)$ for $\mathrm{g}=0.15 \mathrm{~mm}$ and $\mathrm{g}_{\mathrm{u}}=25 \% ; 50 \% ; 75 \% ; 100 \%$.

- Figure 11 shows the dependence $\mathrm{E}_{\mathrm{l}}=\mathrm{f}\left(\mathrm{g}_{\mathrm{u}}\right)$ for $\mathrm{g}=0.15 \mathrm{~mm}$ and $\mathrm{g}_{\mathrm{u}}=25 \% ; 50 \% ; 75 \% ; 100 \%$.

- Figure 12 shows the dependence $\mathrm{R}_{\mathrm{m}}=\mathrm{f}\left(\mathrm{g}_{\mathrm{u}}\right)$ for $\mathrm{g}=0.20 \mathrm{~mm}$ and $\mathrm{g}_{\mathrm{u}}=25 \% ; 50 \% ; 75 \% ; 100 \%$.

- Figure 13 shows the dependence $\varepsilon=\mathrm{f}\left(\mathrm{g}_{\mathrm{u}}\right)$ for $\mathrm{g}=0.20 \mathrm{~mm}$ and $\mathrm{g}_{\mathrm{u}}=25 \% ; 50 \% ; 75 \% ; 100 \%$.

- Figure 14 shows the dependence $E_{1}=f\left(g_{u}\right)$ for $g=0.20 \mathrm{~mm}$ and $g_{u}=25 \% ; 50 \% ; 75 \% ; 100 \%$. 


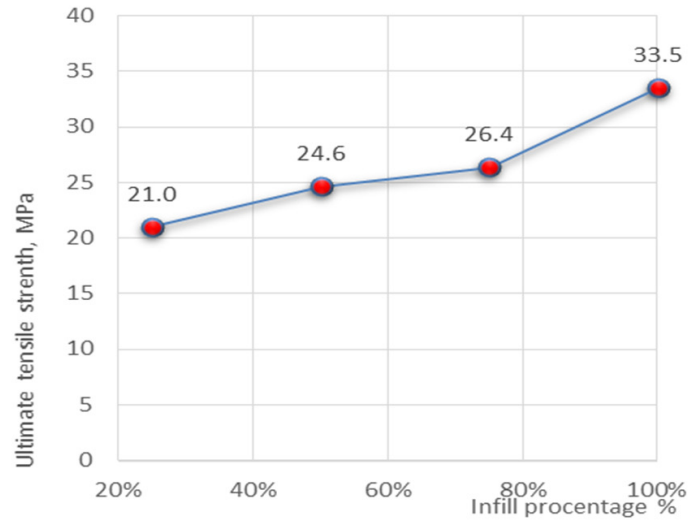

Fig. 6. Dependence $R_{m}=f\left(g_{u}\right)$ for $g=0.1 \mathrm{~mm}$.

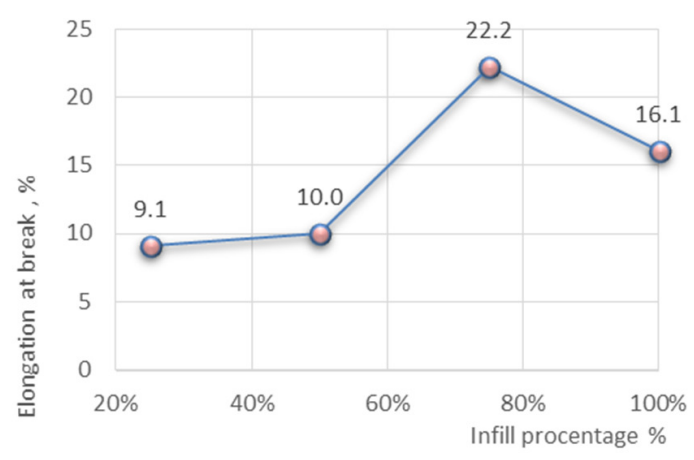

Fig. 7. Dependence $\varepsilon=\mathrm{f}\left(\mathrm{g}_{\mathrm{u}}\right)$ for $\mathrm{g}=0.1 \mathrm{~mm}$.

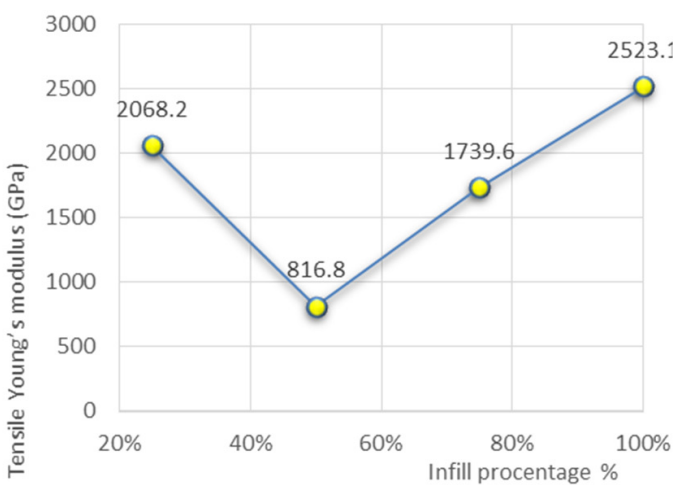

Fig. 8. Dependence $\mathrm{E}_{1}=\mathrm{f}\left(\mathrm{g}_{\mathrm{u}}\right)$ for $\mathrm{g}=0.1 \mathrm{~mm}$.

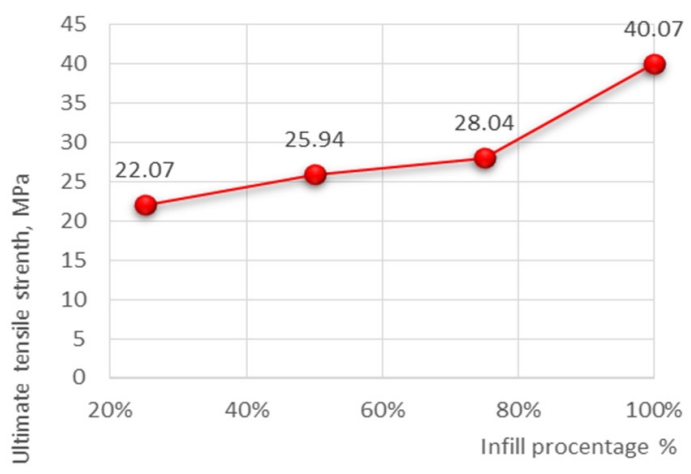

Fig. 9. Dependence $R_{m}=f\left(g_{u}\right)$ for $g=0.15 \mathrm{~mm}$.



Fig. 10. Dependence $\varepsilon=\mathrm{f}\left(\mathrm{g}_{\mathrm{u}}\right)$ for $\mathrm{g}=0.1 \mathrm{~mm}$.

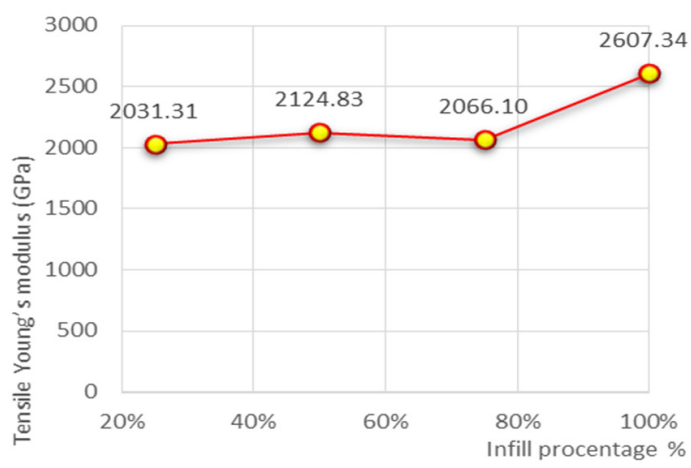

Fig. 11. Dependence $\mathrm{E}_{1}=\mathrm{f}\left(\mathrm{g}_{\mathrm{u}}\right)$ for $\mathrm{g}=0.15 \mathrm{~mm}$.

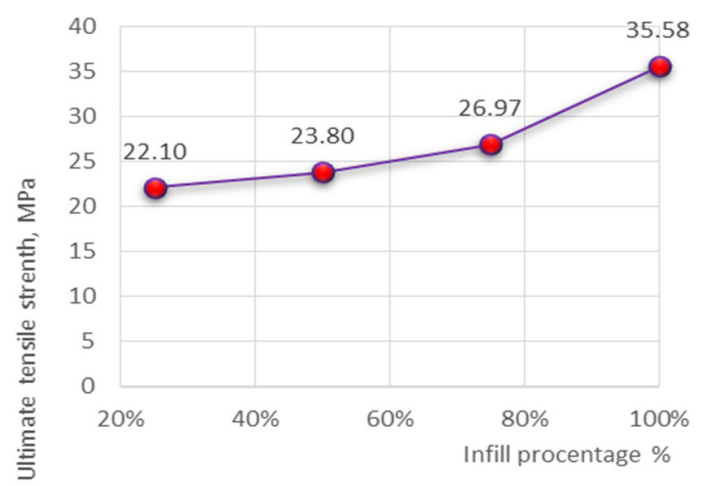

Fig. 12. Dependence $R_{m}=f\left(g_{u}\right)$ for $g=0.20 \mathrm{~mm}$.

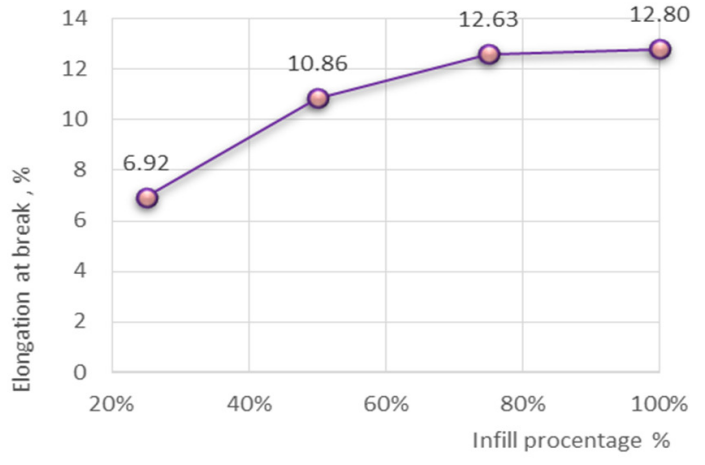

Fig. 13. Dependence $\varepsilon=f\left(g_{u}\right)$ for $g=0.20 \mathrm{~mm}$. 


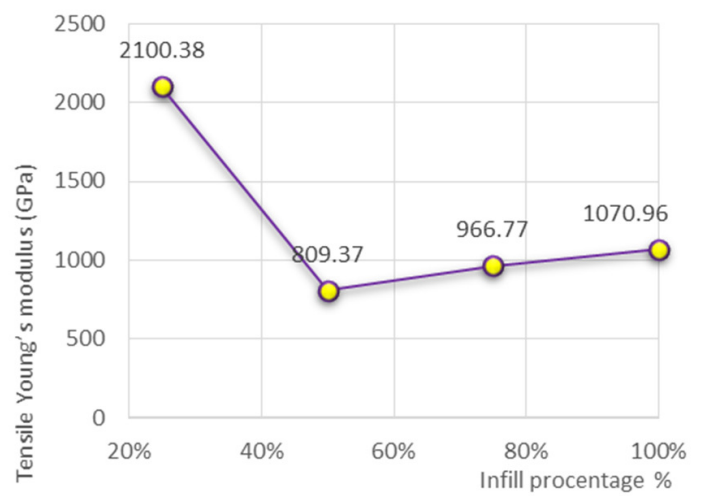

Fig. 14. Dependence $E_{1}=f\left(g_{u}\right)$ for $g=0.20 \mathrm{~mm}$.

\section{B. Shore D Hardness}

The Shore D Hardness for 50,75 , and $100 \% \mathrm{~g}_{\mathrm{u}}$ can be seen in Figure 15



\section{CONCLUSIONS}

The objective of the paper was to establish the variation of the mechanical characteristics of the PLA material, deposited by $3 \mathrm{D}$ printing, depending on the parameters of the technological process. We have started from the characteristics of the raw material (Table I) which show a wide range of characteristic values: $\mathrm{R}_{\mathrm{m}}$ varying from 15.5 to $2 \mathrm{MPa}$, and $\varepsilon=34.5 \pm 8.1 \%$. From the analysis of the obtained results it was found that the values of ultimate tensile strength $\left(\mathrm{R}_{\mathrm{m}}\right)$, are

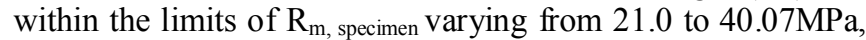
and for $\varepsilon_{\text {specimen }}$ from 6.92 to $16.1 \%$. By comparison with the values from manufacturers' data sheets it is found that $R_{m \text {, specimen }}$ represents only $55.6 \%$ of the maximum value of $R_{m}$ and for $\varepsilon$ the values obtained on specimens are below the recommended lower limit for the raw material $\varepsilon_{\text {brut, min }}=26.4 \%$. Graphs were drawn that express the dependence of the CM of the tested specimens according to the infill percentage $\mathrm{CM}=$ $\mathrm{f}\left(\mathrm{g}_{\mathrm{u}}\right)$, in which $\mathrm{g}_{\mathrm{u}}=25 \% ; 50 \% ; 75 \% ; 100 \%$, for different thicknesses of the deposited layer $(\mathrm{g}=0.1,0.15,0.20 \mathrm{~mm})$. The analysis of the experimental data showed that the maximum value of $\mathrm{R}_{\mathrm{m} \text {, test piece }}=40.07 \mathrm{MPa}$ resulted in the conditions $\mathrm{g}=$ $0.15 \mathrm{~mm}$ and $\mathrm{g}_{\mathrm{u}}=100 \%$.

Given that the thickness of the layer of the deposited material changed to $\mathrm{g}=0.20 \mathrm{~mm}$ and the infill percentage remained the same $g_{u}=100 \%$, a decrease in ultimate tensile strength was observed, which reached the value $R_{m}$, specimen $=$ $35.8 \mathrm{MPa}$. This phenomenon can be explained by the low cohesion of the deposited layers, which involves establishing the influence of the deposition temperature. The flow rate of the raw material is directly proportional to the thickness of the layer as can be seen in Table I. Various studies [5, 16-19] have shown that the ultimate tensile strength increases with the thickness of the deposited layer. In this study, although the maximum value was highlighted for the layer thickness of $0.15 \mathrm{~mm}$, a higher elongation at break is observed in the specimens with a layer thickness of $0.1 \mathrm{~mm}$. All graphs reveal better performance with the increase of infill percentage and less influence of the layer thickness (similar results). It is well known that despite the fact that results can be less satisfying, surely other criteria can be accomplished by using 3D printing.

In this context, further experiments could be developed to evaluate the effect of other input factors of the manufacturing process on the behavior of the parts in the tensile stresses of the material. Regarding Hardness, there is no correlation between the infill percentage and the Shore D Hardness, because of the shell layers (thickness of $0.8 \mathrm{~mm}$ ) and bottom and top thickness of the layers applied on all infill types of specimens. Further research and possible modification of the shell structure might reveal different results in this direction.

\section{REFERENCES}

[1] N. Mohan, P. Senthil, S. Vinodh, and N. Jayanth, "A review on composite materials and process parameters optimisation for the fused deposition modelling process," Virtual and Physical Prototyping, vol. 12, no. 1, pp. 47-59, Jan. 2017, https://doi.org/10.1080/17452759. 2016.1274490.

[2] T. N. A. T. Rahim, A. M. Abdullah, and H. M. Akil, "Recent Developments in Fused Deposition Modeling-Based 3D Printing of Polymers and Their Composites," Polymer Reviews, vol. 59, no. 4, pp. 589-624, Oct. 2019, https://doi.org/10.1080/15583724.2019.1597883.

[3] H. Yilmaz and M. K. Turan, "FahamecV1:A Low Cost Automated Metaphase Detection System," Engineering, Technology \& Applied Science Research, vol. 7, no. 6, pp. 2160-2166, Dec. 2017, https://doi.org/10.48084/etasr.1464.

[4] B. Belarbi, M. E. A. Ghernaout, and T. Benabdallah, "Implementation of a New Geometrical Qualification (DQ) Method for an Open Access Fused Filament Fabrication 3D Printer," Engineering, Technology \& Applied Science Research, vol. 9, no. 3, pp. 4182-4187, Jun. 2019, https://doi.org/10.48084/etasr.2689.

[5] M. Vaezi and C. K. Chua, "Effects of layer thickness and binder saturation level parameters on 3D printing process," The International Journal of Advanced Manufacturing Technology, vol. 53, no. 1, pp. 275284, Mar. 2011, https://doi.org/10.1007/s00170-010-2821-1.

[6] B. M. Tymrak, M. Kreiger, and J. M. Pearce, "Mechanical properties of components fabricated with open-source 3-D printers under realistic environmental conditions," Materials \& Design, vol. 58, pp. 242-246, Jun. 2014, https://doi.org/10.1016/j.matdes.2014.02.038.

[7] A. Lanzotti, M. Grasso, G. Staiano, and M. Martorelli, "The impact of process parameters on mechanical properties of parts fabricated in PLA with an open-source 3-D printer," Rapid Prototyping Journal, vol. 21, no. 5, pp. 604-617, Jan. 2015, https://doi.org/10.1108/RPJ-09-20140135 .

[8] M. Tomanik, M. Żmudzińska, and M. Wojtków, "Mechanical and Structural Evaluation of the PA12 Desktop Selective Laser Sintering Printed Parts Regarding Printing Strategy," 3D Printing and Additive Manufacturing, Mar. 2021, https://doi.org/10.1089/3dp.2020.0111.

[9] C. M. González-Henríquez, M. A. Sarabia-Vallejos, and J. RodriguezHernandez, "Polymers for additive manufacturing and 4D-printing: Materials, methodologies, and biomedical applications," Progress in Polymer Science, vol. 94, pp. 57-116, Jul. 2019, https://doi.org/10.1016/ j.progpolymsci.2019.03.001. 
[10] R. T. L. Ferreira, I. C. Amatte, T. A. Dutra, and D. Bürger, "Experimental characterization and micrography of 3D printed PLA and PLA reinforced with short carbon fibers," Composites Part B: Engineering, vol. 124, pp. 88-100, Sep. 2017, https://doi.org/10.1016/ j.compositesb.2017.05.013.

[11] Z. Zhang, O. Ortiz, R. Goyal, and J. Kohn, "13 - Biodegradable Polymers," in Handbook of Polymer Applications in Medicine and Medical Devices, K. Modjarrad and S. Ebnesajjad, Eds. Oxford: William Andrew Publishing, 2014, pp. 303-335, https://doi.org/10.1016/B978-0323-22805-3.00013-X.

[12] "Creality 3D Printing Filament: Creality Ender Filaments, Online InStock - Creality3D Store ${ }^{\circledR}$ Official Store for Creality 3D Printers and Accessories," Creality $3 d$ Official. https://www.creality3dofficial.com/ collections/filament (accessed Jul. 24, 2021).

[13] D20 Committee, "Test Method for Tensile Properties of Plastics by Use of Microtensile Specimens," ASTM International. https://doi.org/ 10.1520/D1708-18.

[14] "Inventor Software," Autodesk. https://www.autodesk.com/products/ inventor/overview (accessed Jul. 24, 2021).

[15] A. García-Domínguez, J. Claver, A. M. Camacho, and M. A. Sebastián, "Analysis of General and Specific Standardization Developments in Additive Manufacturing From a Materials and Technological Approach," IEEE Access, vol. 8, pp. 125056-125075, 2020, https://doi.org/10.1109/ACCESS.2020.3005021.

[16] A. García-Domínguez, J. Claver, A. M. Camacho, and M. A. Sebastián, "Analysis of General and Specific Standardization Developments in Additive Manufacturing From a Materials and Technological Approach," IEEE Access, vol. 8, pp. 125056-125075, 2020, https://doi.org/10.1109/ACCESS.2020.3005021.

[17] N. Li, Y. Li, and S. Liu, "Rapid prototyping of continuous carbon fiber reinforced polylactic acid composites by 3D printing," Journal of Materials Processing Technology, vol. 238, pp. 218-225, Dec. 2016, https://doi.org/10.1016/j.jmatprotec.2016.07.025.

[18] M. A. S. Anwer and H. E. Naguib, "Study on the morphological, dynamic mechanical and thermal properties of PLA carbon nanofibre composites," Composites Part B: Engineering, vol. 91, pp. 631-639, Apr. 2016, https://doi.org/10.1016/j.compositesb.2016.01.039.

[19] F. Ning, W. Cong, J. Qiu, J. Wei, and S. Wang, "Additive manufacturing of carbon fiber reinforced thermoplastic composites using fused deposition modeling," Composites Part B: Engineering, vol. 80, pp. 369-378, Oct. 2015, https://doi.org/10.1016/j.compositesb.2015.06.013. 